\title{
The Role of Denial in the 'Theft of Nature': Comparing Biopiracy and Climate Change
}

\author{
Tanya Wyatt ${ }^{1} \cdot$ Avi Brisman ${ }^{2,3}$
}

Published online: 14 September 2016

(C) The Author(s) 2016. This article is published with open access at Springerlink.com

\begin{abstract}
Since its inception, green criminology has highlighted, examined and analysed environmental degradation and destruction. The 'theft of nature' is both an example and a driver of illegal and 'lawful but awful' acts and omissions that degrade the environment. Even though this theft is widespread and sometimes well known, it persists because powerful actors put forward an influential narrative of denial that obstructs interventions. This paper explores the role of denial in two thefts of nature-biopiracy and climate change-and compares and contrasts the manifestations of denial that contribute to their continuation. We consider the 'appeal to higher loyalties' (economic interests over environmental concerns), and discuss the implications if such denial goes unchallenged and remains the central narrative.
\end{abstract}

\section{Introduction}

The 'theft of nature' and natural resources is an on-going concern that is an example of and contributes to global environmental degradation and destruction. A core purpose of green criminology is to examine and analyse the causes of environmental harm and thus the motivations of such theft (see, e.g., South and Brisman 2013; White and Heckenberg 2014). In this paper, we argue that the 'theft of nature' is able to persist despite being widespread and at times well known because of the influential narrative of denial put forward by powerful actors. This narrative of denial obstructs interventions and protective measures that otherwise would enable steps to be taken to counter the stealing and exploitation of the planet's finite natural resources. We explore the role of denial in two

Tanya Wyatt

tanya.wyatt@northumbria.ac.uk

1 Northumbria University, Ellison Building, Newcastle upon Tyne NE1 8ST, UK

2 Eastern Kentucky University, 521 Lancaster Avenue, Richmond, VA 40475, USA

3 Queensland University of Technology, Brisbane, QLD, Australia 
thefts of nature-biopiracy and climate change-by comparing and contrasting the manifestations of denial that, in part, enable these environmental harms to continue.

We chose to compare biopiracy and climate change for two reasons. First, the two harms are largely different in their degree of visibility. Whereas climate change is well known and ubiquitous, biopiracy is sometimes hidden - and at other times accepted —and may have more isolated impacts. Second, the scale of environmental harm caused by both is also largely different. Whilst climate change is and will potentially impact millions of people, biopiracy, though still important and damaging, affects fewer individuals. Our point is to determine if - for significantly different green crimes - the narratives and discourses of denial are similar or if different tactics are used to obstruct and misdirect. Within our analysis, we reflect on the role of powerful actors in promulgating and perpetuating particular discourses to advance their interests.

We begin with an overview of biopiracy and related concepts. Drawing on Cohen's (2001) 'states of denial', we describe the form which denial takes in cases of biopiracy and the effects thereof. This is followed by an investigation of the role and manifestation of denial in the on-going and prevalent debates about climate change, where we distinguish between 'scepticism' and 'denial', before considering various typologies of denial as they relate to climate change. Here, we return to Cohen's 'states of denial'-first presented in our discussion of biopiracy-but also contemplate climate change denial in light of Sykes and Matza's (1957) 'techniques of neutralization', as well as the contributions of Pretty (2013) and Washington and Cook (2011). While our discussion here is decidedly UScentric, given the US's significant greenhouse gas emissions and the role that it should play in international efforts to address climate change (but has not largely due to the prevalence of climate change denial in the US), we find it not only appropriate but relevant for Europe and the rest of the world, to focus on US-climate change denial. After discussing some of the effects of climate change denial, we compare and contrast the dynamics of denial in both biopiracy and climate change with particular emphasis on the 'appeal to higher loyalties' that is evident in both-specifically, the dynamic whereby economic interests are prioritised over environmental concerns. This leads us to a discussion of the implications for the victims of biopiracy and climate change if such denial goes unchallenged and remains the central narrative.

\section{Biopiracy and States of Denial}

\section{What is Biopiracy?}

Corporations need to create new products and as an element of developing these, they have teams that search for possible ingredients in naturally occurring compounds and/or organisms. These compounds are then the subject of research to investigate if they have potential applications in medicines or other commercial products (US Department of the Interior 2009). When this happens openly and legally, the search for such potential new compounds is referred to as 'bioprospecting', which can be defined narrowly as 'the worldwide search for plants with special properties, such as for medicinal use' (White 2013: 91) or more broadly as 'the exploration of natural resources in order to find commercially viable products, most likely pharmaceuticals' (Wyatt 2014: 230). When this takes place illegally and illegitimately, it is called 'biopiracy'. 
The word 'biopiracy' was apparently first used by a non-governmental worker in Canada, who encountered such illegal exploitation during the course of his work at the Rural Advancement Foundation International (Robinson 2010). The concept arose from frustration with the 'appropriation and monopolisation of long-held medicinal and agricultural knowledge about nature, as well as the related physical resources (plants, animals and their components)' (Robinson 2010: 39). 'Appropriation' occurs when corporations take knowledge from indigenous communities without compensation and without recognition. Essentially, this is pillaging or theft of the knowledge that has been within these communities for generations. 'Monopolisation', as discussed more below, is the corporate ownership of the products generated from the indigenous knowledge and the intellectual property rights over this knowledge.

Although the term 'biopiracy' may be new, Crosby (1993) describes 'bioprospecting' as having taken place at least since the colonial period, when exploration for new plants and animals, and ultimately new products, was one of the many ways in which indigenous people and their knowledge were exploited. Thus, biopiracy is an evolution of this exploitation. Rather than the colonial powers exploiting indigenous people and pillaging their knowledge, corporations are the powerful actors now seeking new products (South 2007). Furthermore, biopiracy encompasses the contemporary power of corporations due to inequities between them and others, particularly indigenous people, brought about by modern technological and institutional structures. (Robinson 2010). As is evident in Colombia, for instance, these structures - courts, trade agreements and patents - tend to favour the interests of powerful corporations and Western institutions over indigenous and local people (Goyes and South 2016). In Colombia, the result is farmers are prohibited from collecting and planting seeds from their own lands-a practice that has been happening for centuries based on traditional knowledge.

Scholars defining biopiracy agree on the element of exploitation through the lack of compensation and recognition. For instance, Reid (2010: 77) defines biopiracy as the 'process of taking indigenous people's knowledge without compensation'. Shiva (2001: 49) links this process of taking to global institutional structures, and thus defines biopiracy as 'the use of intellectual property systems to legitimise the exclusive ownership and control over biological resources and biological products and processes that have been used over centuries in non-industrialised cultures'. Mgbeoji's (2006: 13) definition is similar and further highlights the unequal dynamics embedded in the relationship: biopiracy is the 'asymmetrical and unrequited movement of plants and TKUP [traditional knowledge of the uses of plants] from the South to the North through the processes of the international institutions and the patent system'. Goyes and South (2016) expand the concept of biopiracy further to include land grabs that are technically legal, but which displace indigenous people from their land. Again, corporations and powerful actors are those that benefit from this practice, and in instances of land grabs, with the help or complicity of the state.

While intellectual property regimes are necessary for technological growth, Western institutions perpetuate and legitimate the exploitation of indigenous knowledge through a biased globalised patent system and specific view of intellectual property. The global patent system has been created by Western developed nations, which recognise only certain forms of 'proof' of knowledge (Wyatt 2014). Oral and non-written histories, which pass on traditional knowledge, are not seen in all courts or patent systems as evidence of intellectual property. Integral to this process is the inequitable balance of power between those Western multinational corporations that seek to profit from indigenous knowledge and utilise this biased Western legal system to protect their interests and those for whom 
the use of natural resources has a long cultural tradition. The existence of globalised legal patent systems is a key part of how corporations construct their denial of any wrongdoing in cases where uncompensated and unrecognised indigenous knowledge has resulted in patented profitable products. The power of corporations also enables them to deny biopiracy in other ways as described below.

\section{States of Denial}

Cohen (2001) identifies three categories of denial: (1) literal denial; (2) interpretive denial; and (3) implicatory denial. Literal denial is 'factual' or 'blatant' denial: 'the assertion that something did not happen or is not true' (Cohen 2001: 7). With literal denial, 'the fact or knowledge of the fact is denied', but with interpretive denial, 'the raw facts (something happened) are not being denied. Rather, they are given a different meaning from what seems apparent to others' (Cohen 2001: 7). Implicatory denial does not involve an attempt 'to deny either the facts or their conventional interpretation. What are denied or minimized are the psychological, political or moral implications that conventionally follow' (Cohen 2001: 8). Implicatory denial, then, is 'not a refusal to acknowledge reality, but a denial of its significance or implications.... Unlike literal or interpretive denial, knowledge itself is not at issue, but doing the 'right' thing with this knowledge' (Cohen 2001: 9).

For Cohen, the most blatant manifestation of denial — that of outright denial — is but one form. Other more subtle tactics to cope with guilt, anxiety and other negative feelings associated with a person's or corporation's actions include discrediting those who have been victims or who are uncovering the wrongdoing, renaming the actions to avoid scrutiny and justifying the actions. This is not limited to individuals, but can be a collective mechanism of assuaging guilt or responsibility that is adopted by organisations. Cohen (2001: 4) explains that denial is 'understood as an unconscious defence mechanism', but also describes some forms of denial as highly organised and calculated. For instance, political denial is conscious, calculated, cynical and transparent. Denying wrongdoing is a chosen strategic ignorance on the part of the organisation. This denial may be what Cohen describes as interpretative. It may also be 'official denial', where it is highly organised and public. The stance of the organisation glosses over the truth through techniques of spindoctoring and manipulation. The collective denial then by organisations is structural and embedded - an almost necessary feature of the organisation's practices and success. It is a combination of 'professional ethics, traditions of loyalty and secrecy, mutual reciprocity or codes of silence' (Cohen 2001: 4). The denial covers the breadth of agents involved in the wrongdoing. This clearly means denial of the victims, but it also means denial of the perpetrators, of the findings of the scientists and of the observers or witnesses (scientists and other experts in courts). We will now unpack how these forms of denial present themselves in instances of biopiracy, which will include a discussion of the effects of biopiracy and the impacts of the denial of biopiracy. We will return to Cohen's 'states of denial' in our discussion of the denial of climate change later in this paper.

\section{Denial in Action in Biopiracy}

The first manifestation of denial in terms of biopiracy is 'official denial' that takes the form of literal denial. Corporations do not admit that they have taken knowledge from indigenous communities. For example, researchers for Syngenta had travelled to Tanzania in search of new varieties of plants to introduce into the horticultural commercial market (Barnett 2006). The company's records indicate that one of the specific varieties that it 
found had no 'commercial significance'. Yet, this variety was used to create a popular patented hybrid Busy Lizzie plant. Syngenta claimed it had invented the new plant (Barnett 2006). Denial is first evident in Syngenta's claims that the variety had no commercial significance, when in fact it was crucial to a successful commercialised hybrid plant. Denial is also evident upon further scrutiny of Tanzania's wildlife in that the hybrid Busy Lizzie that Syngenta 'invented' and patented may well be occurring naturally in the region where their scientists were looking for new varieties (Barnett 2006). Other official forms of denial are evident in corporations' and scholars' assertions that biopiracy does not exist because patenting is legally acceptable (Chen 2006; Heald 2003). This immediately removes from existence the victims and the perpetrator.

Other tactics incorporating denial are 'interpretative' in nature. Drahos (2000) points to claims that even if indigenous knowledge actually has been used in developing new products, this knowledge actually contributes very little to the formulation of the end product. Presumably, the argument is then that because the traditional knowledge did not impact significantly upon product creation, there is no need for compensation or recognition. Therefore, there is not actually any biopiracy occurring. Similarly, in cases where corporations do acknowledge that some amount of indigenous knowledge has contributed to the development of new medicines or agricultural products, the right to compensation and recognition is deflected by claims that it is too difficult to attribute monetary value to the portion of information that has been taken from the traditional knowledge (Drahos 2004). With such instances of combined knowledges, it is difficult to unpack which information is worth what in the final product. Finally, the existence of biopiracy may be recognised, but in relation to the threat of lawsuits and claims against industries rather than biopiracy being harmful to indigenous people. For example, Nash (2001) says that the idea of biopiracy scares away multi-national companies from exploring developing countries and thus hurts the economic opportunities of both the corporations and the local people who would have benefited from the presence of the corporation. This final point links to Sykes and Matza's (1957) techniques of neutralisation, discussed below, and the 'appeal to higher loyalties'. Economic opportunities and benefits for corporations are prioritised over the cultural traditions and unrecognised ownership over indigenous knowledge.

\section{Effects of Biopiracy and Biopiracy Denial}

Biopiracy, though it is denied in various ways, does have negative impacts upon the communities where it happens. Theft of culture in the form of pillaging nature and knowledge may be difficult to quantify, but there are financial and environmental implications. Biopiracy can lead to the loss of potential economic opportunities. By stealing the knowledge and claiming ownership over products created from this knowledge, transnational corporations impede and take the means for developing nations to fund significant development projects (Barnett 2006). For instance, as Wyatt (2014) notes, regarding the Busy Lizzie example described above, Tanzanians could grow the same hybridized Busy Lizzies. They could then sell them to Western consumers. Syngenta, though, has been given a patent over the native flora of Tanzania by a Western court, so the people who raised the plant for generations cannot benefit from this potential business. Western corporations have monopolies over these products, and people who have been cultivating and using the source of these products for generations are not able to compete on the global market and the control over their own natural resources is located in these Western institutions who have been granted the ownership. In addition, endemic plants and crops that may at one time only have been in developing countries in the South are now 
cultivated in the North (Wyatt 2012). Again, this robs indigenous communities of potential economic opportunities.

As indicated, there are also environmental implications to biopiracy. If local people do not profit or benefit from their own environment and natural resources, they have less incentive to preserve its biodiversity (Barnett 2006), which may lead to environmental harm and degradation. Plants and animals that have medicinal and agricultural value get reduced to genetic components that are valued only instrumentally. This monetised value is shared just with the corporations, rather than all of the worth of these species and their attributes (cultural, social and so forth) benefiting the whole community (Robinson 2010). Indigenous communities have even less incentive to preserve their natural resources because they are excluded from the global governance system overseeing markets and trading (Liang 2011). The irony is that the very source of new medicines, horticultural products and economic opportunities becomes degraded because the local people living next to it cannot or will not protect the environment because corporations are stealing their knowledge of it.

Denial of biopiracy makes it invisible to not only the indigenous communities who are victims of it, but also to the global community (Wyatt 2014). By not being visible, such 'theft of nature' is allowed to continue unquestioned, unabated and unchallenged. Part of this denial is enabled by the global governance system that allows the patenting of this knowledge and thus legitimises the theft. Denying that indigenous communities have some intellectual property over their centuries of practices is a human rights violation that has cultural, financial and environmental impacts. These impacts differ from those of climate change, discussed in the next part.

\section{Climate Change Denials}

Anticipated or possible impacts of climate change include increases in the intensity, frequency, and duration of droughts, floods, heat waves, and hurricanes, and indirect cultural, social and political effects, such as civil unrest, geopolitical tensions, and violence; changes already taking place entail: from the shrinking of glaciers, thawing of permafrost, later freezing and earlier break-up of ice on rivers and lakes, and global bleaching of coral reefs to the lengthening of mid- to high-latitude growing seasons, earlier flowering of trees, emergence of insects, and egg-laying in birds, and the loss of living species at a level comparable to the extinction event that wiped out the dinosaurs 65 million years ago (see, e.g., Brisman 2013: 245-63). With such wide-ranging transformations and such potential serious and irreversible consequences, one would think, then, that discussions of how to mitigate and adapt to climate change would preoccupy public discourse and political debate. But as van der Linden et al. (2015: 758) point out, 'most Americans continue to view climate change as a nonurgent issue and consistently rank it well below the economy, terrorism, health care, and a myriad of other issues (Pew Research Center 2014). Similarly, as Roberts (2015) has recently reported, climate change 'is very few people's top issue, or even top five; few people vote based on it or contact their representatives about it' - a finding that, like van der Linden and colleagues', confirms White's (2008: 35) observation that the '[s]everity of any particular issue... does not necessarily translate into the prominence given to that particular issue'. Thus, while there is vast scientific consensus on anthropogenic climate change (Brisman 2012: 49; Washington and Cook 2011: 19; White and Kramer 2015) - about $97 \%$ of the top climate scientists believe that the Earth is 
warming and that this is due to human activity (Singer 2015: 10; van der Linden et al. 2015: 760)—as Achenbach (2015: 41) explains, '[m]any people in the United States—a far greater percentage than in other countries-retain doubts about that consensus or believe that climate activists are using the threat of global warming to attack the free market and industrial society generally'. ${ }^{1}$ Or, as Pretty (2013: 475) puts it, 'climate change... grows more of a concern as evidence emerges, yet denial remains strong'.

In this section of our paper, we examine the nature of and reasons for climate change denial, and endeavour to explain both the different types of denial that is occurring, why such denial is taking place, and the effects of this denial. Before proceeding, however, a brief discussion of the difference between 'scepticism' and 'denial' is in order.

\section{'Scepticism' Versus 'Denial'}

People who express reluctance to make changes in their lifestyles and personal consumption practices in order to reduce their carbon footprint or who articulate reservations about national or international measures to address climate change (e.g., regulations, taxes) often seek to justify their positions on the grounds of 'scepticism'. This has been especially so among politicians in the United States' Republican Party (see, e.g., Krugman 2015; McClanahan and Brisman 2015). For example, Marco Rubio, the junior U.S. Senator from Florida who was a candidate for the U.S. presidency in 2016, has asserted, "I think all science deserves scepticism" (quoted in Farrell 2014), while Jeb Bush, the former Governor of Florida who was also candidate for the U.S. presidency in 2016, replied to questions about how the U.S. should respond to climate change were he elected with the statement, "I'm a skeptic. I'm not a scientist" (quoted in West 2014).

The statements by Rubio and Bush reflect a misunderstanding of the relationship of science to scepticism and to what may more properly be known as 'denial'. As Washington and Cook (2011: 1) make clear, '[s]kepticism is about seeking the truth and realizing the world is a complex place. Skepticism is about stepping away from superstition and dogma. Genuine scepticism in science is one of the ways that science progresses, examining assumptions and conclusions' (citing Pittock 2009). "Denial", on the other hand, 'is something very different, it is a refusal to believe something no matter what the evidence' (Washington and Cook 2011: 1). Whereas scepticism in science is a good practice- '[a]n objective scientist should be skeptical: one should not jump to conclusions or believe something simply because it is fashionable and agrees with current dogma' (Washington and Cook 2011: 1)—scepticism of science, as conveyed by Rubio and Bush, is quite another matter. 'Those in denial', Washington and Cook (2011: 1) continue, 'demonstrate a "wilful ignorance" and invoke logical fallacies to buttress their unshakeable beliefs (Specter 2009)... Denial isn't about searching for truth, it's about the denial of a truth one doesn't like. So skepticism and denial are in some ways opposites'. Similarly, to paraphrase Knight and Greenberg (2011), there is a difference between honest scientific scepticism and disagreement, on the one hand, and the use of denial, cloaked in the language of 'scepticism', on the other, that is used to promote an ideology or engage in deception (on behalf of, say, corporate interests in the fossil fuel industry (see generally

\footnotetext{
1 While denial of anthropogenic climate change and the harm it has caused or may contribute to is more prevalent in the U.S. than elsewhere-which is rather perverse given that the U.S. alone produces approximately twenty percent of global carbon emissions and far more emissions per capita (Smith and Leiserowitz 2012:1021) - it does occur in other countries, such as the United Kingdom (see, e.g., Booker 2015; Goldenberg 2013a, b; Ridley 2013).
} 
Levy and Egan 2003). Rubio and Bush, like many others, have lifted an aspect of the knowledge-producing process out of science-'scepticism' - and have used it to call that very process into question because it (science) has generated evidence that does not comport with their (or their corporate funders") "market fundamentalism" (Oreskes and Conway 2008, quoting Soros 1997) and commitment to unfettered economic growth.

While Rubio and Bush's scepticism of the entire scientific endeavour and denial of evidence of anthropogenic climate change bear strong resemblances to each other, it is important to recognise that climate change denial is not a uniform or singular phenomenon. In other words, while there may be a cumulative effect or impact of climate change denial (discussed below), the denial of climate change actually takes a number of different forms and is manifested in different types of arguments. As such, it may be more proper to think of climate change denials, rather than climate change denial. In the next section, we consider different types of climate change denial-what we refer to as 'typologies of denial'-as well as why such denials are taking place.

\section{Typologies of Denial}

In their influential article, 'Techniques of Neutralization', Sykes and Matza (1957) challenged the dominant view in criminology at the time that, drawing on Cohen (1955), centred on the supposed oppositional values of delinquent subcultures. Sykes and Matza (1957: 664) described this prevailing perspective as one in which ' $[t]$ he basic characteristic of the delinquent subculture, it is argued, is a system of values that represents an inversion of the values held by respectable, law-abiding society. The world of the delinquent is the world of the law-abiding turned upside down and its norms constitute a countervailing force directed against the conforming social order'. Taking issue with the suggestion that delinquent individuals approve of delinquency, Sykes and Matza (1957: 667) presented an alternative formulation, arguing that delinquent individuals are able to engage in lawbreaking behaviour by employing certain 'techniques of neutralization' and which they divided into five major types: denial of responsibility; denial of injury; denial of the victim; condemnation of the condemners; and the appeal to higher loyalties. Such 'justifications', Sykes and Matza (1957) maintained, were necessary before the delinquent act or omission in order to weaken social control and the moral bind of the law, as well as after the act or omission in order to protect the delinquent individual from self-blame and reproach from others. While evidence suggests that offenders often excuse or justify their crimes using the neutralisations proffered by Sykes and Matza (see, e.g., Scully and Marolla 1984), industry actors may be able to refrain from changing their business practices and mitigating their greenhouse gas emissions, and corporate and state leaders may be able to prevent action from being taken on climate change, by engaging in the same neutralisations:

- Denial of responsibility [denying that climate change is occurring as a result of human activities (see Kramer and Michalowski 2012); arguing that it would be pointless for the U.S. to adopt regulations if other leading global polluters, such as China and India, do not follow suit (see, e.g., Berman 2014); denying that corporations intended to contribute to climate change with their fossil fuel emissions (Oreskes and Conway 2008)];

- Denial of injury [arguing that '[c]limate change has done more good than harm so far and is likely to continue doing so for most of this century' (Ridley 2013); claiming that 'natural' disasters are 'normal' (see White and Heckenberg 2014: 113 for a discussion)]; 
- Denial of the victim [failing to recognise that the impacts of climate change will be distributed unevenly/unequally and that various groups are and will continue to be in different positions to adapt to climate change (see Hanstad and Prosterman 2014; see Brisman 2015 for a discussion)];

- Condemnation of the condemners [attacking climate scientists and arguing that they have collaborated on a vast hoax (see Achenbach 2015; Farrell 2014; Oreskes and Conway 2008) or have manipulated data to secure funding (Brisman 2012)];

- Appeal to higher loyalties [expressing a commitment to a radical free market ideology that opposes any restrictions on the pursuit of capitalism, no matter the justification (Oreskes and Conway 2008); privileging economic interests over and above anything else (White and Heckenberg 2014)].

Drawing on Sykes and Matza, Cohen (2001) identifies three categories of denial (discussed above): (1) literal denial; (2) interpretive denial; and (3) implicatory denial. All three of Cohen's categories of denial appear in the context of climate change. Some engage in literal denial: they challenge the scientific evidence that the Earth's climate is changing or, if they acknowledge change, argue that it is 'natural' (see, e.g., Evans 2014; Krugman 2010; Revkin 2008; Washington and Cook 2011: 98; White and Kramer 2015). Others engage in interpretive denial: they argue not that the Earth's climate is not changing but that the impacts will not be as negative as predicted (see, e.g., Ridley 2013; Washington and Cook 2011: 58)—what Washington and Cook (2011: 98) call 'spin' and what McCright and Dunlap (2000) refer to as "the social construction of its "non-problematicity" (quoting Freudenburg 2000). Finally, implicatory denial is exhibited at both the individual citizen level and at the corporate-state level: individuals may acknowledge that the Earth is warming and the climate is changing due to human activities but may deny any responsibility as citizens to act or intervene, rationalising 'What can an ordinary person do?' 'Someone else will deal with it' (see Agnew 2012; van der Linden et al. 2015); corporate and state actors, on the other hand, may know what can and should be done and may have the means to do it but may suggest that the risk (to jobs, the economy, corporate profits, political jobs) is too great (see, e.g., Peoples 2013; Takepart.com 2013), even if it is not (see, e.g., Krugman 2010; see generally Krugman 2014). As Washington and Cook (2011: 98) explain, implicatory denial 'is not negation of information about climate change per se, rather a failure to incorporate this knowledge into everyday life or transform it into social action. People have access to information, accept this information as true, yet for a variety of reasons choose to ignore it (Norgaard 2006a and b)' (emphasis in original).

Whereas Sykes and Matza (1957) generated their 'techniques of neutralization' (three of which contain the word 'denial') to support their argument that delinquency does not arise from an inversion of conventional values and allegiance to alternative moralities, and Cohen (2001) promulgated his three types of denial in order to demonstrate how individuals and groups avoid or evade uncomfortable personal and political realities, both classifications of denial can be applied to climate change (for a more in-depth application of Cohen's ideas to climate change, see Brisman and South 2015). Pretty (2013), on the other hand, is less interested in neutralisations and denials, in general, than in the specifics of climate change and thus he focuses on what he calls 'denial narratives' that he argues are preventing the necessary changes in policy and behaviour, despite the scientific evidence that anthropogenic sources of carbon and other greenhouse gases are contributing to rising atmospheric concentrations that, in turn, are causing climate change. Pretty's (2013: 489) six 'denial narratives' are as follows: 
1. Economic growth can continue without impact on natural capital and ecosystem services, and such impacts would anyway not result in negative effects on GDP;

2. Increases in GDP linearly improve life satisfaction and well-being through increased consumption;

3. Technological innovation will inevitably produce sufficient changes in the energy intensity of material goods and so will protect source and sink natural capital;

4. Harm caused to natural capital and ecosystem services has no feedback on human well-being;

5. As the poorest countries need to consume more, their pathways to economic development will have to be the same as those adopted by the currently affluent countries;

6. Affluent countries do not need to reduce consumption, as conventional economic growth will eventually deliver environmental benefits.

These narratives, while specific to climate change, possess some of the flavour of Sykes and Matza's neutralisations and Cohen's types of denial. For instance, the fourth narrative- ' $[\mathrm{h}]$ arm caused to natural capital and ecosystem services has no feedback on human well-being'-resembles Sykes and Matza's denial of injury and Cohen's interpretive denial. Whereas Sykes and Matza's 'techniques of neutralization' suggest how denial occurs and Cohen's types of denial help reveal what is being denied, Pretty's narratives hint at the reasons behind denial of climate change-a commitment to the economic and political systems at the heart of the global capitalist system.

To more fully appreciate why and how climate change denial is transpiring, as well as what, exactly, about climate change is being denied, it is helpful to consider the relationship between 'ignorance' and 'denial'. According to Cohen (2001: 51), 'denial' refers to 'the maintenance of social worlds in which an undesirable situation (event, condition, phenomenon) is unrecognized, ignored or made to seem normal'. Proctor (2008: 3), in arguing for the study of ignorance, distinguishes between 'ignorance as native state (or resource), ignorance as lost realm (or selective choice), and ignorance as deliberately engineered and strategic ploy (or active construct)'. As Proctor (2008: 4, emphasis in original) explains, ignorance as native state can 'be a prompt for knowledge, insofar as we are constantly striving to destroy it-fact by fact. Ignorance has both ontogeny and phylogeny: babies start out ignorant and slowly come to know the world; hominids have become sapient over millions of years from the happy accident of upright posture and not knowing what to do with our idle hands'. Such ignorance-'a place where knowledge has not yet penetrated' (Proctor 2008: 4, emphasis in original) - is viewed as a deficit that can be overcome. With ignorance as lost realm or as 'selective choice' or as 'passive construct', 'the decision to focus on this is therefore invariably a choice to ignore that' (2008: 7, emphasis in original). Here, Proctor (2008: 7) explains, '[i]gnorance is a product of inattention, and since we cannot study all things, some by necessity-almost all, in factmust be left out'. Were individual and collective inaction with respect to climate change products of ignorance as native state or ignorance as lost realm, then we-those who accept the scientific evidence that the Earth's climate is changing as a result of human activities and who fear that this is happening for the worse-would have a substantial, but manageable task of trying to 'educate the masses' and alter collective consciousness and concern. The difficulty, however, is that ignorance may not be an omission or gap: it can be "an actively engineered part of a deliberate plan" (Proctor 2008: 9). It is here-with the deliberate production of doubt or uncertainty-that ignorance is made and maintained and becomes denial. 
Washington and Cook (2011: 11, 43-63), drawing on Diethelm and McKee (2009), identify five types of climate change denial arguments-or five different strategies intended to perpetuate doubt or uncertainty about the existence, causes and consequences of anthropogenic climate change: (1) conspiracy theories; (2) fake experts; (3) impossible expectations; (4) misrepresentations and logical fallacies; and (5) cherry-picking. We consider each of these in turn.

With conspiracy theories, deniers do not 'admit that scientists have independently studied the evidence to reach their conclusions. Instead they claim that scientists are engaged in a complex and secretive conspiracy' (Washington and Cook 2011: 12), such as with the Climate Research Unit email controversy in 2009 (dubbed 'Climategate'), in which thousands of emails and other documents from the University of East Anglia's (UEA) Climate Research Unit were made public, after being illegally obtained through hacking of the UEA's computers-documents that climate change deniers claimed proved that mainstream climate scientists were fabricating data and overstating the case for human influence on climate change (Brisman 2012: 53-54; Brisman and South 2015: 451; Washington and Cook 2011: 43-44). While Climategate was unmasked as a manufactured controversy concocted by opponents of climate action and while everyone in UEA's climate research group was cleared of wrongdoing (Brisman 2012: 53-54; Washington and Cook 2011: 44), the belief that climate change is a hoax promulgated by thousands of colluding scientists persists. As Achenbach (2015: 41) rightly points out, however, '[t]he idea that hundreds of scientists from all over the world would collaborate on such a vast hoax is laughable — scientists love to debunk one another'. Or as Krugman (2009: A21), writing around the time of Climategate, opined, 'I'd call this a crazy conspiracy theory, but doing so would actually be unfair to crazy conspiracy theorists. After all, to believe that global warming is a hoax you have to believe in a vast cabal consisting of thousands of scientists - a cabal so powerful that it has managed to create false records on everything from global temperatures to Arctic sea ice'.

Fake experts are 'individuals purporting to be experts but whose views are inconsistent with established knowledge' (Washington and Cook 2011: 12). This tactic is often accompanied by the 'denigration of established experts' in an attempt to discredit their work (Washington and Cook 2011: 12). Whilst such 'fake experts' are often exposed and their work proven incorrect (see, e.g., Kaufman 2009), the 'media loves controversy and will seek to provoke argument' (Washington and Cook 2011: 93). The result is that fake experts are able to 'exploit the media's balancing norm' (Brisman 2012: 58), thereby receiving media attention that is disproportionate to the actual degree of disagreement regarding climate change and humans' responsibility for the increased global temperatures over the last century. As Achenbach (2015: 41) explains, '[t]he news media give abundant attention to such mavericks, naysayers, professional controversialists, and table thumpers. The media would also have you believe that science is full of shocking discoveries made by lone geniuses. Not so. The (boring) truth is that it usually advances incrementally, through the steady accretion of data and insights gather by many people over many years'.

Washington and Cook's third denial argument-impossible expectations of what research can deliver-can be understood by considering how, for example, "[t]he uncertainties of climate models are used as an excuse to reject them with all evidence of humaninduced global warming' (2011: 47). This expectation of complete accuracy misunderstands the scientific process, in general, and models, in particular. As Washington and Cook (2011: 49) explain, '[m]odels are in a constant state of development include more processes, rely on fewer approximations and increase their resolution as computer power. The complex and non-linear nature of climate means there will always be a process of 
refinement and improvement. The main point is that we now know enough to act. Models have evolved to the point where they successfully predict long-term trends and are now developing the ability to predict more chaotic, short-term changes. They don't need to be exact in every respect to give us an accurate overall trend.... To wait for $100 \%$ certainty would mean society would never act on anything' (emphasis in original).

With misrepresentations and logical fallacies, opposing arguments are distorted, making them easier to refute. One such argument is that "climate has changed naturally in the past and therefore current climate change must be natural" —an argument, Washington and Cook 2011: 51) contend, is akin to asserting that "forest fires have occurred naturally in the past so any current forest fires must be natural".' The argument that 'past climate change' refutes the influence of human activities on global warming, while popular among climate change deniers, ignores the science that demonstrates the net positive feedback that further warms the Earth. 'Ironically', Washington and Cook (2011: 51) point out, 'past climate change actually provides evidence that human actions can affect climate now' (emphasis in original).

Finally, cherry-picking entails 'selectively drawing on isolated papers that challenge the consensus, and thus ignores the broader body of research' (Washington and Cook 2011: 12). As Washington and Cook (2011: 51) remind us, 'science operates in something of an adversarial process. People put forward data and ideas, and these get tested by other scientists to see if the data stands up to scrutiny. Sometimes it doesn't and the authors themselves accept there was an error or another explanation for their data. That is how scientific consensus is achieved'. Climate change deniers, however, often select isolated papers that challenge the consensus, excluding the broader body of research that has developed the consensus.

The different types of denial-the diverse ways in which and reasons why climate change denial has and continues to occur (as demonstrated by the discussion above of Sykes and Matza (1957), Cohen (2001), Pretty (2013) and Washington and Cook (2011) - and the range of groups of individuals involved in climate change denial (see Singer 2015), may make it harder, at times, to challenge those denials and deniers. The overall impact of climate change denial, however, is comparatively easier to discern. In the last section of this part, we consider the effects of climate change denial. From there, we engage in a comparison of biopiracy denial and climate change denial, before turning to some of the broader implications of these denials of environmental problems.

\section{Effects of Denial}

Whilst environmental groups who support individual and collective efforts to reduce greenhouse gas emissions must convince people (on individual, state, federal, and international levels) to act - to change their behaviours and practices or to agree to legislation to moderate or mitigate anthropogenic climate change-climate change deniers win with inaction [see McCright and Dunlap 2000: 509 (citing Hirschman (1991)]. Indeed, as Achenbach (2015: 47) explains, 'In the U.S., climate change skeptics have achieved their fundamental goal of halting legislative action to combat warming. They haven't had to win the debate on the merits; they've merely had to fog the room enough to keep laws governing greenhouse gas emissions from being enacted'. Through the various strategies, described above, climate change deniers have succeeded in sowing doubt about the causes and consequences of climate (see Brisman and South 2015). For climate change deniers, then, the equation is simple: $d o u b t=$ inaction $=$ victory. 
But this is not all. As Krugman (2009: A21) laments, '[t]hey don't like the political and policy implications of climate change, so they've decided not to believe in it-and they'll grab any argument, no matter how disreputable, that feeds their denial.... [T] he deniers are choosing, willfully, to ignore [the threat of climate change], placing future generations... in grave danger, simply because it's in their political interest to pretend that there's nothing to worry about'.

Indeed, by sacrificing the needs of the larger society—and those of the entire Earth, its ecosystems and its human and nonhuman animal populations-for the demands of smaller wealthy/elite social groups, climate change deniers have "made a mockery of the scientific process and placed the very definition of "science" at stake, transforming the contextual and contingent nature of science so that it now appears "plural and open-ended" [Brisman 2012: 63 (quoting Carvalho 2007: 238)]. This 'contempt for hard science', to use Krugman's (2009: A21) phrasing - this treatment of science as a 'dismissable endeavor' (Carvahlo 2007: 238) - threatens science as a whole; it also runs the risk of challenging the very means by which we might (eventually) mitigate and adapt to climate changethrough technological innovation. While the conviction that technology will 'save the day' can constitute a form of denial, as outlined by Pretty (2013: 489) above, and while there are dangers to holding too much faith in technological fixes (see Brisman 2015), undercutting the entire scientific enterprise is hardly a prudent path for learning more about our natural world or for developing better ways to live on Earth after our despoliation of it.

\section{Comparison of Biopiracy Denial and Climate Change Denial}

Whereas the denial of climate change has received scholarly and media attention, the denial (or existence) of biopiracy has not received the same amount of scrutiny. Thus, there are theories such as Diethelm and McKee's (2009) and Washington and Cook's (2011), which outline five strategies being employed by climate change deniers. Denial of biopiracy is perhaps more hidden. This may be due, in part, to the global patent system mentioned above, which often avoids critical scrutiny, thereby making this form of 'theft of nature' appear to be accepted. These five strategies, all clearly evident in the discourse on climate change denial, are not applicable to biopiracy denial. There does not appear to be conspiracy theories, fake experts, or impossible expectations. To some degree, there are misrepresentations (although not logical fallacies), but less regarding the science related to production creation and more pertaining to the relationship between the corporations, the indigenous people and their knowledge or the economic viability of potential products. For instance, in the example of the Busy Lizzie, there was a misrepresentation of one variety of the plant as commercially insignificant (Barnett 2006). Finally, in terms of cherry-picking, this may happen in cases of biopiracy, but may be less in relation to the relevant science, but more so in regards to information on how the product was developed from beginning to end. Again, in the instance of the Busy Lizzie, though local people had shown company employees the varieties of these plants this was not at first acknowledged (Barnett 2006).

Likewise, the five techniques of neutralisation have a more limited relevance and application in regards to biopiracy then they do for climate change. Denial of responsibility is not really possible when there is literal denial in the first place. There is, then, nothing for which to be responsible. Similarly, if there is no harm, there is no injury or victim to deny. In cases of biopiracy, we have yet to discover evidence of condemning the condemners, so corporations have not adopted the tactic of blaming indigenous communities or NGOs for 
the theft of traditional knowledge. We can, however, envision instances in which people who employ the term, 'biopiracy', are condemned on the grounds that the term negates the hard work of scientists to develop life-saving treatments for disease, thereby frustrating research and the dissemination of helpful medicines. Alternatively, Goyes and South (2016) indicate that corporations do blame indigenous communities for not utilizing their traditional knowledge more widely to benefit more people. As alluded to above, the fifth technique - the appeal to higher loyalties - is central to the biopiracy denial discourse and a significant justification for the status quo with respect to behaviours impacting on climate change. The radical free market and economic prosperity are the most important parts of society. The economic prosperity is not of indigenous communities; it is of the powerful Western corporations, which influence not only the governance structures of property and knowledge, but also the discourses of denial.

Numerous factors and industries contribute to climate change and the impacts and effects are both more global and more diverse than those relating to biopiracy, which means attempts to mitigate climate change have much wider and more significant economic implications than biopiracy. It stands to reason then that the arsenal of weapons to deny climate change by the diverse array of stakeholders is larger and more sophisticated. That being said, economic motivations are at the heart of both denials, be it governments and politicians protecting their economies or single corporations trying to increase their profits. For both, biopiracy and climate change, Cohen's (2001) states of denial are employed to protect the elites' economic interests. There is literal denial that either takes place. Interpretative denial is also used where information is spun to support that neither occurs. Implicatory denial may too be used in both cases. Presumably, corporations that have used indigenous knowledge to create products may acknowledge the source of the information, but then do nothing about compensating or recognising that source. Knowing the various forms that denial takes may not only help to devise strategies to combat biopiracy and progress the efforts to combat climate change, but may also inform the intervention and prevention policies of other environmental harms.

\section{Conclusion}

'Denial is as old as humanity', write Washington and Cook (2011: 71). While there is a long history of denial of environmental problems, in this paper, we have attempted to describe two examples of the 'theft of nature' that have occurred and are continuing to transpire because of denial: biopiracy and climate change. We have also attempted to reveal how various businesses and industries and state-corporate/politico-corporate alliances have significant vested economic interests in continuing to do exploit and appropriate indigenous knowledge in the case of biopiracy and to block legislation that might limit the production of greenhouse gases, in the case of climate change. Whilst these interests are powerful, they are not omnipotent. So why, then, do people continue to engage in 'environmental denial' - in 'biopiracy denial' and 'climate change denial'? The reasons may be as numerous as the types of denial discussed in this paper but fundamentally, these forms of denial persist because the implications of acceptance are significant (see Levy and Egan 2003: 820)_because 'there's no going back once you end denial' (Friedman 2014: A19). 
Open Access This article is distributed under the terms of the Creative Commons Attribution 4.0 International License (http://creativecommons.org/licenses/by/4.0/), which permits unrestricted use, distribution, and reproduction in any medium, provided you give appropriate credit to the original author(s) and the source, provide a link to the Creative Commons license, and indicate if changes were made.

\section{References}

Achenbach, J. (2015). The age of disbelief. National Geographic, 227, 30-47.

Agnew, R. (2012). It's the end of the world as we know it: The advance of climate change from a criminological perspective. In R. White (Ed.), Climate change from a criminological perspective (pp. 13-25). London: Springer.

Barnett, A. (2006). The new piracy: how the west "steals" Africa's plants. Swiss and British firms are accused of using the scientific properties of plants from the developing world to make huge profits while giving nothing to the people there. The Observer, 27 August.

Berman, R. (2014). The angry GOP backlash to Obama's historic climate accord. The Atlantic, 12 November. http://www.theatlantic.com/politics/archive/2014/11/the-angry-gop-backlash-to-obamashistoric-climate-accord/382676/. Accessed 15 June 2016.

Booker, C. (2015). The fiddling with temperature data is the biggest science scandal ever. The Telegraph, 7 February.

Brisman, A. (2012). The cultural silence of climate change contrarianism. In R. White (Ed.), Climate change from a criminological perspective (pp. 41-70). London: Springer.

Brisman, A. (2013). Not a bedtime story: Climate change, neoliberalism, and the future of the Arctic. Michigan State International Law Review, 22(1), 241-289.

Brisman, A. (2015). "Multicolored" green criminology and climate change's achromatopsia. Contemporary Justice Review, 18(2), 178-196.

Brisman, A., \& South, N. (2015). New "folk devils", denials and climate change: Applying the work of Stanley Cohen to green criminology and environmental harm'. Critical Criminology, 23(4), 449-460.

Carvahlo, A. (2007). Ideological cultures and media discourses on scientific knowledge: Re-reading news on climate change. Public Understanding of Science, 16(2), 223-243.

Chen, J. (2006). There is no such thing as biopiracy... It's a good thing too. McGeorge Law Review, 37, $1-32$.

Cohen, A. K. (1955). Delinquent boys: The culture of the gang. New York: Free Press.

Cohen, S. (2001). States of denial: Knowing about atrocities and suffering. Cambridge: Polity Press.

Crosby, A. (1993). Ecological imperialism: The biological expansion of Europe, 900-1900. Cambridge: Cambridge University Press.

Diethelm, P., \& McKee, M. (2009). Denialism: What is it and how should scientists respond? European Journal of Public Health, 19(1), 2-4.

Drahos, P. (2000). Indigenous knowledge, intellectual property and biopiracy: Is a global biocollecting society the answer? European Intellectual Property Review, 22(6), 245-250.

Drahos, P. (2004). Towards an international framework for the protection of traditional group knowledge and practice. In UNCTAD-commonwealth secretariat workshop on elements of national sui generis systems for the preservation, protection and promotion of traditional knowledge, innovations and practices and options for an international framework. Geneva, Switzerland.

Evans, R. (2014). Global warming not stopped, will go on for centuries: WMO. Reuters, 24 March.

Farrell, P. B. (2014). Climate science is a hoax: Big oil, GOP, God say so. MarketWatch, 22 May.

Freudenburg, W. R. (2000). Social constructions and social constrictions: Toward analyzing the social construction of "the naturalized" as well as "the natural". In G. Spaargen, A. Mol, \& F. H. Buttel (Eds.), Environment and global modernity (pp. 103-119). London: Sage.

Friedman, T. L. (2014). The world is fast. The New York Times, 5 November, A19.

Goldenberg, S. (2013a). How Donors Trust distributed millions to anti-climate groups. The Guardian, 14 February. http://www.guardian.co.uk/environment/2013/feb/14/donors-trust-funding-climate-denialnetworks. Accessed 15 June 2016.

Goldenberg, S. (2013b). Secret funding helped build vast network of climate denial thinktanks. The Guardian, 14 February. http://www.guardian.co.uk/environment/2013/feb/14/funding-climate-changedenial-thinktanks-network. Accessed 15 June 2016.

Goyes, D. R., \& South, N. (2016). Land-grabs, biopiracy and the inversion of justice in Colombia. British Journal of Criminology, 56(3), 558-577. 
Hanstad, T. \& Prosterman, R. (2014). How the poor get washed away. The New York Times. 15 January, A23.

Heald, P. J. (2003). Rhetoric of biopiracy. Cardozo Journal of International and Comparative Law, 11, 519-546.

Hirschman, A. (1991). The rhetoric of reaction. Cambridge: Harvard University Press.

Kaufman, L. (2009). Dissenter on warming expands his campaign. The New York Times, 10 April, A13.

Knight, G., \& Greenberg, J. (2011). Talk of the enemy: Adversarial framing and climate change discourse. Social Movement Studies, 10(4), 323-340.

Kramer, R., \& Michalowski, R. (2012). Is global warming a state-corporate crime? In R. White (Ed.), Climate change from a criminological perspective (pp. 71-88). New York: Springer.

Krugman, P. (2009). Betraying the planet. The New York Times, 28 June, A21.

Krugman, P. (2010). Building a green economy. The New York Times Magazine, 11 April, MM34.

Krugman, P. (2014). Crazy climate economics. The New York Times, 12 May, A23.

Krugman, P. (2015). Things to celebrate. The New York Times, 25 December, A25.

Levy, D. L., \& Egan, D. (2003). A neo-Gramscian approach to corporate political strategy: Conflict and accommodation in the climate change negotiations. Journal of Management Studies, 40(4), 803-829.

Liang, B. (2011). Global governance: Promoting biodiversity and protecting indigenous communities against biopiracy. Journal of Commercial Biotechnology, 17(3), 248-253.

McClanahan, B., \& Brisman, A. (2015). Climate change and peacemaking criminology. Critical Criminology, 23(4), 417-431.

McCright, A. M., \& Dunlap, R. E. (2000). Challenging global warming as a social problem: An analysis of the conservative movement's counter-claims. Social Problems, 47(4), 499-522.

Mgbeoji, I. (2006). Global biopiracy: Patents, plants and indigenous knowledge. Vancouver: UBC Press.

Nash, R. (2001). Who benefits from biopiracy? Phytochemistry, 56(5), 403-405.

Norgaard, K. (2006a). "People want to protect themselves a little bit": Emotions, denial and social movement nonparticipation. Sociological Inquiry, 76(3), 372-396.

Norgaard, K. (2006b). We don't really want to know. Organisation and Environment, 19(3), 347-370.

Oreskes, N., \& Conway, E. M. (2008). Challenging knowledge: How climate science became a victim of the cold war. In R. Proctor \& L. Schiebinger (Eds.), Agnotology: The making and unmaking of ignorance (pp. 55-89). Redwood City, CA: Stanford University Press.

Peoples, S. (2013). Obama climate change push draws industry criticism. Associated Press, 4 July. http:// news.yahoo.com/obama-climate-change-push-draws-071050111.html. Accessed 15 June 2016.

Pew Research Center. (2014). Thirteen years of the public's top priorities. http://www.people-press.org/ interactive/top-priorities/. Accessed 15 June 2016.

Pittock, A. B. (2009). Climate change: The science, impacts and solutions. Clayton: CSIRO Publishing.

Pretty, J. (2013). The consumption of a finite planet: Well-being, convergence, divergence and the nascent green economy. Environmental and Resource Economics, 55(4), 475-499.

Proctor, R. N. (2008). Agnotology: A missing term to describe the cultural production of ignorance (and its study). In R. Proctor \& L. Schiebinger (Eds.), Agnotology: The making and unmaking of ignorance (pp. 1-33). Redwood City, CA: Stanford University Press.

Reid, J. (2010). Biopiracy: The struggle for traditional knowledge rights. American Indian Law Review, 34, 77-98.

Revkin, A. C. (2008). Skeptics on human climate impact seize on cold spell. The New York Times, 2 March, 14.

Ridley, M. (2013). Why climate change is good for the world. The Spectator, 19 October. http://www. spectator.co.uk/features/9057151/carry-on-warming/. Accessed 15 June 2016.

Roberts, D. (2015). College students are making global warming a moral issue. Here's why that scares people. Vox, 29 April. http://www.vox.com/2015/4/29/8512853/fossil-fuel-divestment. Accessed 15 June 2016.

Robinson, D. (2010). Locating biopiracy: Geographically and culturally situated knowledges. Environment and Planning, 42, 38-56.

Scully, D., \& Marolla, J. (1984). Convicted rapists' vocabulary of motive: Excuses and justifications. Social Problems, 31, 530-544.

Shiva, V. (2001). Protect or plunder? Understanding intellectual property rights. London: Zed Books.

Singer, M. (2015). Climate change denial: The organized creation and emotional embrace of unsupported science claims. Anthropology News, 56(1-2), 10.

Smith, N., \& Leiserowitz, A. (2012). The rise of global warming skepticism: Exploring affective image associations in the united states over time. Risk Analysis, 32(6), 1021-1032.

Soros, G. (1997). The capitalist threat. Atlantic Monthly, February, 45-58. 
South, N. (2007). The "corporate colonisation of nature": Bio-prospecting, bio-piracy and the development of green criminology. In P. Bierne \& N. South (Eds.), Issues in green criminology: Confronting harms against environments, humanity and other animals (pp. 230-247). London: Willan.

South, N., \& Brisman, A. (Eds.). (2013). Routledge international handbook of green criminology. London: Routledge.

Specter, M. (2009). Denialism: How irrational thinking hinders scientific progress, harms the planet and threatens our lives. London: Penguin Press.

Sykes, G., \& Matza, D. (1957). Techniques of neutralization: A theory of delinquency. American Sociological Review, 22(6), 664-670.

Takepart.com. (2013). Are you ready for even more Katrinas and Sandys? Yahoo!News, 11 June. http:// news.yahoo.com/ready-even-more-katrinas-sandys-042923722.html. Accessed 15 June 2016.

US Department of the Interior. (2009). Benefits-sharing in the National Parks. Environmental impact statement: What is bioprospecting?. http://www.nature.nps.gov/benefitssharing/whatis.cfm. Accessed 15 June 2016.

van der Linden, S., Maibach, E., \& Leiserowitz, A. (2015). Improving public engagement with climate change: Five "best practice" insights from psychological science. Perspectives on Psychological Science, 10(6), 758-763.

Washington, H., \& Cook, J. (2011). Climate change denial: Heads in the sand. London: Earthscan.

West, J. (2014). Jeb Bush on climate change: "I'm a skeptic." Mother Jones, 16 December. http://www. motherjones.com/politics/2014/12/jeb-bush-climate-change-skeptic. Accessed 15 June 2016.

White, R. (2008). Crimes against nature: Environmental criminology and ecological justice. London: Willan.

White, R. (2013). Environmental harm: An eco-justice perspective. Bristol: Policy Press.

White, R., \& Heckenberg, D. (2014). Green criminology: An introduction to the study of environmental harm. London: Routledge.

White, R. \& Kramer, R. (2015). Critical criminology and the struggle against climate change ecocide. Critical Criminology. 23/4 November: 383-399.

Wyatt, T. (2012). Biopiracy. In M. Beare (Ed.), Encyclopedia of transnational crime and justice (pp. 29-30). London: Sage.

Wyatt, T. (2014). Invisible pillaging: The hidden harm of corporate biopiracy. In P. Davies, P. Francis, \& T. Wyatt (Eds.), Invisible crimes and social harms (pp. 161-177). London: Palgrave Macmillan. 